\title{
Reduction of Hexavalent Chromium by Viable Cells of Chromium Resistant Bacteria Isolated from Chromite Mining Environment
}

\author{
Satarupa Dey, Baishali Pandit, and A. K. Paul \\ Microbiology Laboratory, Department of Botany, University of Calcutta, 35 Ballygunge Circular Road, Kolkata 700019, India \\ Correspondence should be addressed to A. K. Paul; amalk_paul@yahoo.co.in
}

Received 27 April 2014; Revised 10 July 2014; Accepted 15 July 2014; Published 10 August 2014

Academic Editor: Yong Sik Ok

Copyright (C) 2014 Satarupa Dey et al. This is an open access article distributed under the Creative Commons Attribution License, which permits unrestricted use, distribution, and reproduction in any medium, provided the original work is properly cited.

\begin{abstract}
Environmental contamination of hexavalent chromium $[\mathrm{Cr}(\mathrm{VI})]$ is of serious concern for its toxicity as well as mutagenic and carcinogenic effects. Bacterial chromate reduction is a cost-effective technology for detoxification as well as removal of Cr(VI) from polluted environment. Chromium resistant and reducing bacteria, belonging to Arthrobacter, Pseudomonas, and Corynebacterium isolated from chromite mine overburden and seepage samples of Orissa, India, were found to tolerate $12-18 \mathrm{mM} \mathrm{Cr}(\mathrm{VI}) \mathrm{during}$ growth. Viable cells of these isolates were also capable of growing and reducing $100 \mu \mathrm{M} \mathrm{Cr}(\mathrm{VI})$ quite efficiently in Vogel Bonner (V.B.) broth under batch cultivation. Freshly grown cells of the most potent isolate, Arthrobacter SUK 1201, reduced $100 \mu \mathrm{M}$ Cr(VI) in $48 \mathrm{~h}$. Reduction potential of SUK 1201 cells decreased with increase in $\mathrm{Cr}(\mathrm{VI})$ concentration but increased with increase in cell density and attained its maximum at $10^{10}$ cells $/ \mathrm{mL}$. Chromate reducing efficiency of SUK 1201 was promoted in the presence of glucose and glycerol while the highest reduction was at $\mathrm{pH} 7.0$ and $25^{\circ} \mathrm{C}$. The reduction process was inhibited by divalent cations $\mathrm{Ni}$, $\mathrm{Co}$, and $\mathrm{Cd}$, but not by $\mathrm{Cu}$. Similarly, carbonyl cyanide $m$-chlorophenylhydrazone, N,N,-Di cyclohexyl carbodiimide, sodium azide, and sodium fluoride were inhibitory to chromate reduction, while 2,4 dinitrophenol promoted the process. Cells permeabilized by toluene increased the efficiency of $\mathrm{Cr}(\mathrm{VI})$ reduction and, thereby, indicate that Arthrobacter sp. SUK 1201, indigenous to chromite mining environment, could be used as an ideal tool for chromium bioremediation.
\end{abstract}

\section{Introduction}

Mining activities in and around chromite mines, in general, lead to the generation of huge amount of overburden material as well as accumulation of mine seepage waters, which are the main sources of chromium pollution of inland fresh water and farm lands in the vicinity of the mining sites. The chromite mining in the vast area of Orissa, India, is no exception to this generalization $[1,2]$.

In humans, several health hazards are associated with continuous exposure to $\mathrm{Cr}(\mathrm{VI})$. This is mainly because of its carcinogenic as well as mutagenic properties. Workers employed in areas highly contaminated with chromium suffer from nasal irritation and ulceration, skin irritation, eardrum perforation, lung carcinoma [3, 4], bronchial asthma, kidney necrosis, and allergic reactions in the skin. At higher level, chromium is also found to cause oxidative damage to cell membrane, alteration of enzyme specificity, and structural deformation in DNA [5].

Conventional methods used for removal of $\mathrm{Cr}(\mathrm{VI})$ comprised of chemical reduction followed by precipitation through adjustment of $\mathrm{pH}$, ion exchange, and adsorption generate large quantities of solid sludge for disposal and are expensive and lack specificity [6]. Bioremediation, on the other hand, is an ecofriendly alternative for detoxification and removal of Cr-pollutants which uses indigenous microbiota [7]. Microbial reduction of hexavalent chromium has attracted increased interest, as this process not only relieves the toxicity of chromium but also leads to the precipitation at near-neutral $\mathrm{pH}$ for subsequent physical removal [8]. Chromium resistant and reducing bacteria isolated from chromium polluted environments such as tannery effluent and chromite mining environments have played a key role in chromium bioremediation [9-13]. 
During the course of our survey of chromium resistant and reducing bacteria, four efficient chromite reducing strains, namely, Arthrobacter sp. SUK 1201 (MTCC 8728, GenBank accession number JQ 312665), Arthrobacter sp. SUK 1205 (MTCC 8731, GenBank accession number JQ 312666), Pseudomonas putida SKPD 1202 (MTCC 8729), and Corynebacterium paurometabolum SKPD 1204 (MTCC 8730) were isolated from the chromite mining environment of Orissa, India [12-14]. The main objective of the present study was to determine their chromium tolerance along with reduction of $\mathrm{Cr}(\mathrm{VI})$ by viable cells of these selected bacterial isolates in Vogel Bonner (V. B.) broth. Further, attempts have also been made to optimize the cultural conditions for $\mathrm{Cr}(\mathrm{VI})$ reduction by viable cells of the isolate Arthrobacter sp. SUK 1201 in V. B. broth under batch culture and to assess the ability of this isolate as an ideal tool for hexavalent chromium bioremediation.

\section{Materials and Methods}

2.1. Source and Maintenance of Bacterial Cultures. Four chromate reducing bacterial strains, namely, Arthrobacter sp. SUK 1201 (MTCC 8728, GenBank accession number JQ 312665), Arthrobacter sp. SUK 1205 (MTCC 8731, GenBank accession number JQ 312666), Pseudomonas putida SKPD 1202 (MTCC 8729), and Corynebacterium paurometabolum SKPD 1204 (MTCC 8730) isolated from chromite mining environment of Orissa, India [12-14], were used in this study. Arthrobacter sp. SUK 1201 and Arthrobacter sp. SUK 1205 were isolated from chromite mine overburden samples, whereas Pseudomonas putida SKPD 1202 and Corynebacterium paurometabolum SKPD 1204 were isolated from chromite mine seepage samples. For maintenance, the bacterial strains were grown on slopes of peptone yeast extract glucose (PYEG) agar medium supplemented with $2 \mathrm{mM} \mathrm{Cr}$ (VI) [15]. The medium contained (g/L) peptone, 10.0; yeast extract, 5.0; glucose, 3.0, and agar agar, 20.0 ( $\mathrm{pH} 7.0)$. Overnight grown cultures were stored at $4^{\circ} \mathrm{C}$ for future use.

2.2. Chromate Tolerance. Bacterial tolerance to hexavalent chromium was evaluated following broth dilution method of Calomiris et al. [16]. V. B. broth supplemented with different concentrations of $\mathrm{Cr}(\mathrm{VI})(2-20 \mathrm{mM})$ was inoculated with overnight grown cultures and incubated at $35^{\circ} \mathrm{C}$ for 4 days under continuous shaking $(120 \mathrm{rpm})$ in a rotary shaker. Tolerance to $\mathrm{Cr}$ (VI) was calculated by determining the relative growth of the isolates with respect to the growth in control [Cr(VI)-free medium], which was considered as 100. Growth of the isolates was measured by determining the optical density at $540 \mathrm{~nm}$.

2.3. Preparation of Cell Mass. Cell mass for chromate reduction studies was obtained by growing the isolates in PYEG medium at $35^{\circ} \mathrm{C}$ for $24 \mathrm{~h}$ under continuous shaking at $120 \mathrm{rpm}$. The cell mass of the isolates was harvested aseptically by centrifugation $(10,000 \times \mathrm{g})$ at $4^{\circ} \mathrm{C}$ for $10 \mathrm{~min}$, washed $2-3$ times with sterile ice cold Tris buffer ( $\mathrm{pH} 7.0$ ), and suspended in the same buffer following the method of Wang and Xiao [15]. The cell mass was adjusted to a final cell density of $10^{9}$
cells/mL of reduction medium and used for reduction studies. Viability of cells was determined by dilution and plating of the cell suspension on PYEG agar plates. During the course of hexavalent chromium reduction, changes of cell numbers in the reduction medium were determined by counting the total number of cells/mL by using a haemocytometer (Neubauer, Fein-Optik Jena, Germany) and a phase contrast microscope (Zeiss Winkel Model number 148786, Germany).

2.4. Chromate Reduction Assay. Reduction of $\mathrm{Cr}$ (VI) by freshly grown cells of the selected bacterial strains was determined in V. B. broth. Vogel Bonner broth was made up of $2.0 \%$ sterile stock solution of $\mathrm{V}$. B. concentrate. The V. B. concentrate contained (g/L) $\mathrm{K}_{2} \mathrm{HPO}_{4}, 500.0$; $\mathrm{Na}\left(\mathrm{NH}_{4}\right) \mathrm{HPO}_{4} \cdot 4 \mathrm{H}_{2} \mathrm{O}, 175.0$; citric acid, $100.0 ; \mathrm{MgSO}_{4} \cdot 7 \mathrm{H}_{2} \mathrm{O}$, 10.0 , and $2.0 \%$ of $25 \%$ D-glucose 20.0 (pH 7.0) [15]. Medium (20 mL/100 mL flask) was supplemented with separately sterile solution of $100 \mu \mathrm{M} \mathrm{Cr}(\mathrm{VI})$. Flasks were inoculated with viable cells at a density of $10^{9}$ cells/mL under aseptic condition and incubated at $25^{\circ} \mathrm{C}$ under continuous shaking (120 rpm). The cell number and the viability of cells were determined following the same procedure as described in Section 2.3. Control (without cells) and autoclaved cells were also used for each $\mathrm{Cr}(\mathrm{VI})$-reduction assay to monitor any abiotic $\mathrm{Cr}(\mathrm{VI})$ reduction and biosorption of $\mathrm{Cr}(\mathrm{VI})$ by the cell mass.

Reduction of chromium was estimated by measuring the decrease of $\mathrm{Cr}(\mathrm{VI})$ contents in the reaction mixture following 1,5-diphenylcarbazide method [17]. Changes in the population of viable cells, if any, during the process of $\mathrm{Cr}(\mathrm{VI})$ reduction were also monitored by dilution and plating method on PYEG agar.

2.5. Effect of Electron Donors on Chromate Reduction. Chromate reduction by viable cells of Arthrobacter sp. SUK 1201 was studied in presence of various electron donors, such as glucose, glycine, glycerol, acetate, peptone, sucrose, propionate, yeast extract, benzoate, and tryptone. The reduction medium $(20 \mathrm{~mL}$ of $\mathrm{V}$. B. broth/100 mL) was supplemented with sterile $100 \mu \mathrm{M} \mathrm{Cr}(\mathrm{VI})$ along with the electron donors at $0.1 \%(\mathrm{w} / \mathrm{v})$. Conditions of incubation, measurement of growth, harvesting of cells, and estimation of residual hexavalent chromium in the reduction medium were the same as described in earlier sections.

2.6. Effect of Temperature and $\mathrm{pH}$ on Chromate Reduction. Effect of different temperature $\left(20^{\circ}-40^{\circ} \mathrm{C}\right)$ and $\mathrm{pH}\left(6.0_{-}\right.$ 8.0) on the $\mathrm{Cr}(\mathrm{VI})$ reducing capability of viable cells of Arthrobacter sp. SUK 1201 was determined. The effect of $\mathrm{pH}$ was determined at a wide range $(\mathrm{pH}$ 6.0-8.0) using citrate, phosphate, and Tris- $\mathrm{HCl}$ buffers with overlapping $\mathrm{pH}$ range. Chromate concentration, cell density/mL, and incubation conditions were the same as described earlier.

\subsection{Effect of Additional Metal Ions on Chromate Reduction.} Chromate reduction by Arthrobacter sp. SUK 1201 cells was studied in presence of additional metal ions such as $\mathrm{Mn}$ (II), $\mathrm{Co}(\mathrm{II}), \mathrm{Zn}(\mathrm{II}), \mathrm{Cu}(\mathrm{II})$, and $\mathrm{Ni}(\mathrm{II})$. The metals were used as chloride salts, sterilized separately, and added to V. B. broth 
at equimolar $(100 \mu \mathrm{M})$ level of $\mathrm{Cr}(\mathrm{VI})$. Other experimental conditions were the same as described above.

2.8. Effect of Inhibitors on Chromate Reduction. The effect of metabolic inhibitors on chromate reduction by viable cells of Arthrobacter sp. SUK 1201 was investigated using the ATPase inhibitor N,N,-Di cyclohexyl carbodiimide (DCC), protonophore carbonyl cyanide $m$-chlorophenylhydrazone (CCCP), enolase inhibitor sodium fluoride, artificial electron acceptor sodium azide, and 2,4 dinitrophenol (DNP). The inhibitors were separately sterilized and added to the reduction medium at equimolar concentration. Other experimental conditions were the same as described previously.

2.9. Reduction by Permeabilized Cells. Permeabilized cells were obtained by harvesting overnight grown cultures of Arthrobacter sp. SUK 1201, washed, and suspended in sterile Tris- $\mathrm{HCl}$ buffer ( $\mathrm{pH}$ 7.0). Toluene, Triton X100, and Tween 80 were added to the cell suspension at $0.1 \%(\mathrm{v} / \mathrm{v})$ concentration and vortexed for 10 minutes to permeabilize the cells. Chromate reduction assay with these permeabilized cells was performed in the same way as described above, while the untreated cells were used as control.

2.10. Statistical Analysis. All experiments were carried out in triplicate and results represent mean \pm standard error.

\section{Results and Discussion}

Biotransformation of highly toxic and mutagenic hexavalent chromium [18] to relatively nontoxic trivalent $\mathrm{Cr}$ (III) form by chromate reducing bacteria offers an economical as well as ecofriendly option for chromium bioremediation. Four chromate reducing bacterial strains, namely, Arthrobacter sp. SUK, Arthrobacter sp. SUK 1205, Pseudomonas putida SKPD 1202, and Corynebacterium paurometabolum SKPD 1204 were previously isolated and reported from chromite mine overburden and mine seepage samples and found to reduce chromate during growth under aerobic conditions $[12,14]$.

3.1. Chromate Tolerance. Chromium tolerance of the isolates as evident from the relative growth of the isolates in $\mathrm{Cr}(\mathrm{VI})$ supplemented media is represented in Figure 1. A significant difference in the growth of the selected isolates was recorded in V. B. broth supplemented with $2-20 \mathrm{mM}$ of $\mathrm{Cr}(\mathrm{VI})$. As the concentration of chromium increased, the growth of the bacterial isolates decreased. The growth of the isolates was reduced to almost $50 \%$ of the control [without $\mathrm{Cr}(\mathrm{VI})$ ] at hexavalent chromium concentration of $2 \mathrm{mM}$ and was strongly inhibited at $12 \mathrm{mM} \mathrm{Cr}(\mathrm{VI})$. Isolates Arthrobacter sp. SUK 1201 and Corynebacterium paurometabolum SKPD 1204 tolerated up to 18 and $16 \mathrm{mM} \mathrm{Cr}(\mathrm{VI})$, respectively, showing nearly $20 \%$ growth relative to control.

3.2. Chromate Reduction by Viable Cells. Reduction of $\mathrm{Cr}(\mathrm{VI})$ by viable cells has been studied using a variety of microorganisms $[10,19]$ in both aerobic $[20,21]$ and anaerobic conditions $[22,23]$. Monitoring of $\mathrm{Cr}(\mathrm{VI})$ reduction and

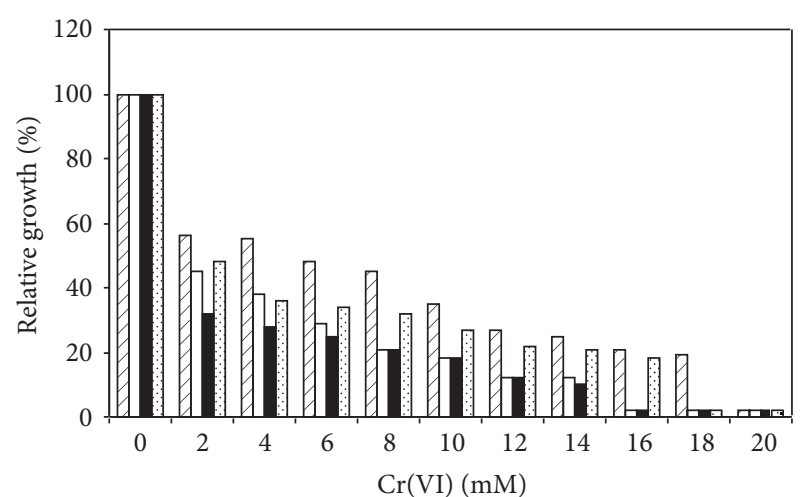

$\triangle$ Arthrobacter sp. SUK 1201

$\square$ Arthrobacter sp. SUK 1205

Pseudomonas putida SKPD 1202

Corynebacterium paurometabolum SKPD 1204

FIGURE 1: Effect of $\mathrm{Cr}(\mathrm{VI})$ concentration on relative growth of bacterial isolates [Arthrobacter sp. SUK 1201, Arthrobacter sp. SUK 1205, Pseudomonas putida SKPD 1202, and Corynebacterium paurometabolum SKPD 1204 were grown in V. B. broth supplemented with different concentrations of $\mathrm{Cr}(\mathrm{VI})$ and relative growth was calculated considering the growth in control as 100].

growth of the suspended cells of all 4 bacterial strains, namely, SUK 1201, SUK 1205, SKPD 1202, and SKPD 1204 (Figure 2) indicates that the strains were very much resistant to $\mathrm{Cr}(\mathrm{VI})$ and reduced it effectively. Both Arthrobacter isolates, that is, SUK 1201 and SUK 1205, completely reduced $100 \mu \mathrm{M}$ $\mathrm{Cr}(\mathrm{VI})$ in $48 \mathrm{~h}$. Reduction of $\mathrm{Cr}(\mathrm{VI})$ was accomplished by gradual discolouration of the medium but the pattern of increase in cell number/mL of medium was different for the different strains. In SUK 1201, cell number increased till $40 \mathrm{~h}$ of incubation and was followed by a decline, while in SUK 1205 , there was a gradual increase till $48 \mathrm{~h}$ of incubation. The other two isolates, Pseudomonas putida SKPD 1202 and Corynebacterium paurometabolum SKPD 1204, could reduce about $90 \%$ of $100 \mu \mathrm{M} \mathrm{Cr}(\mathrm{VI})$ during the same period of incubation. Therefore, based on the limit of $\mathrm{Cr}(\mathrm{VI})$ tolerance $(18 \mathrm{mM})$ and the efficiency of chromate reduction $[100 \mu \mathrm{M}$ $\mathrm{Cr}(\mathrm{VI})$ in $48 \mathrm{~h}$ ], Arthrobacter sp. SUK 1201 was selected for further studies.

3.3. Effect of Initial $\mathrm{Cr}(\mathrm{VI})$ Concentration. The effect of different initial $\mathrm{Cr}(\mathrm{VI})$ concentrations $(50-800 \mu \mathrm{M})$ were tested on $\mathrm{Cr}(\mathrm{VI})$ reducing ability of Arthrobacter sp. SUK 1201. The results presented in Table 1 showed that cells of SUK 1201 completely reduced 50 and $100 \mu \mathrm{M}$ Cr(VI) $24 \mathrm{~h}$ and in $48 \mathrm{~h}$ respectively. The other concentrations of $\mathrm{Cr}(\mathrm{VI})$ were also significantly reduced within $48 \mathrm{~h}$ and about $75 \%$ of total $\mathrm{Cr}(\mathrm{VI})$ was reduced at the highest concentration $(800 \mu \mathrm{M})$ tested. Likewise, chromate reduction by viable cells of different chromate reducing bacterial isolates was found to be influenced by the initial $\mathrm{Cr}(\mathrm{VI})$ concentration $[11,24,25]$. The present study showed that complete reduction failed to occur at higher initial $\mathrm{Cr}(\mathrm{VI})$ concentration (Table 1) which also corroborates the findings of several others [26, 27] 

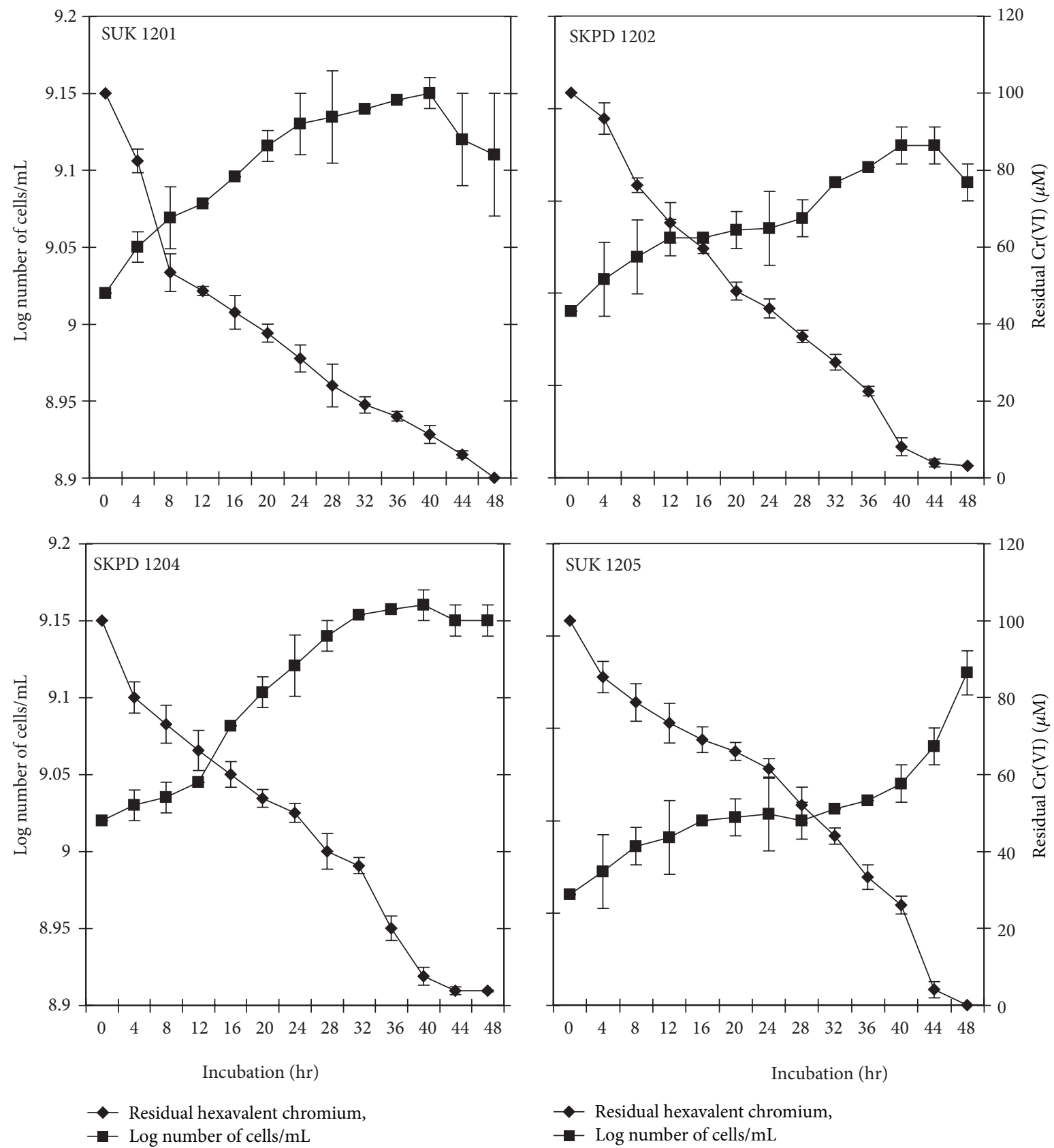

FIGURE 2: Time course of hexavalent chromiumreduction by viable cells of selected bacterial isolates [Arthrobacter sp. SUK1201, Arthrobacter sp. SUK 1205, Pseudomonas putida SKPD 1202, and Corynebacterium paurometabolum SKPD 1204] in V. B. broth under batch culture.

TABle 1: Effect of Cr(VI) concentration on Cr(VI) reduction by Arthrobacter sp. SUK 1201.

\begin{tabular}{|c|c|c|c|c|c|c|c|}
\hline \multirow[t]{2}{*}{ Incubation, hr } & \multicolumn{7}{|c|}{$\begin{array}{c}\% \mathrm{Cr}(\mathrm{VI}) \text { reduced } \\
\text { Concentration of } \mathrm{Cr}(\mathrm{VI}), \mu \mathrm{M}\end{array}$} \\
\hline & 50 & 100 & 200 & 300 & 400 & 600 & 800 \\
\hline 12 & $66.0 \pm 0.7$ & $46.0 \pm 1.2$ & $16.5 \pm 2.6$ & $28.0 \pm 1.2$ & $34.4 \pm 1.9$ & $35.8 \pm 2.2$ & $35.4 \pm 1.9$ \\
\hline 24 & $100.0 \pm 0.0$ & $60.0 \pm 2.1$ & $32.3 \pm 3.1$ & $36.0 \pm 1.6$ & $50.0 \pm 2.3$ & $46.6 \pm 2.1$ & $45.0 \pm 2.6$ \\
\hline 48 & $100.0 \pm 0.0$ & $100.0 \pm 0.0$ & $87.5 \pm 1.5$ & $73.3 \pm 2.3$ & $71.0 \pm 3.5$ & $70.0 \pm 0.8$ & $68.0 \pm 2.5$ \\
\hline
\end{tabular}

$\left(\mathrm{Cr}(\mathrm{VI})\right.$ reduction was carried out in $\mathrm{V}$. B. broth containing $50-800 \mu \mathrm{M}$ of $\mathrm{Cr}(\mathrm{VI})$. The initial cell density was maintained at $10^{9}$ cells $/ \mathrm{mL}$. Incubation: $48 \mathrm{~h}$ at $25^{\circ} \mathrm{C}$ under continuous shaking $(120 \mathrm{rpm})$. Residual $\mathrm{Cr}(\mathrm{VI})$ was estimated by usual diphenylcarbazide method. Results represent mean of triplicate experiments \pm standard error). 
TABLE 2: Effect of cell density on Cr(VI) reduction by viable cells of Arthrobacter sp. SUK 1201.

\begin{tabular}{|c|c|c|c|c|c|}
\hline \multirow[t]{2}{*}{ Incubation, hr } & \multicolumn{5}{|c|}{$\% \mathrm{Cr}(\mathrm{VI})$ reduced } \\
\hline & $10^{6}$ & $10^{7}$ & $10^{8}$ & $10^{9}$ & $10^{10}$ \\
\hline 12 & $5.40 \pm 1.2$ & $14.1 \pm 2.6$ & $20.0 \pm 1.0$ & $41.2 \pm 1.6$ & $66.0 \pm 1.4$ \\
\hline 24 & $19.0 \pm 0.8$ & $24.0 \pm 1.6$ & $30.0 \pm 1.8$ & $64.2 \pm 2.6$ & $76.0 \pm 0.9$ \\
\hline 48 & $34.0 \pm 2.2$ & $48.1 \pm 0.6$ & $75.0 \pm 1.0$ & $100 \pm 0.6$ & $100 \pm 0.4$ \\
\hline
\end{tabular}

$\left(\mathrm{Cr}(\mathrm{VI})\right.$ reduction was carried out in V. B. broth containing $100 \mu \mathrm{M} \mathrm{Cr}(\mathrm{VI})$ and a cell density ranging from $10^{6}-10^{10}$ cells $/ \mathrm{mL}$. Incubation: $48 \mathrm{~h}$ at $25^{\circ} \mathrm{C}$ under continuous shaking $(120 \mathrm{rpm})$. Residual $\mathrm{Cr}(\mathrm{VI})$ was estimated by usual diphenylcarbazide method. Results represent mean of triplicate experiments \pm standard error).

with Arthrobacter sp. Such decrease in chromate reduction capability with the increasing concentration of initial $\mathrm{Cr}(\mathrm{VI})$ might be due to toxicity of chromium to viable whole cells.

3.4. Effect of Initial Cell Density. Reduction of $\mathrm{Cr}(\mathrm{VI})$ increased proportionally with increase in cell density ranging from $10^{6}$ to $10^{10}$ cells $/ \mathrm{mL}$ (Table 2). Arthrobacter sp. SUK 1201 cells reduced $100 \mu \mathrm{M} \mathrm{Cr}(\mathrm{VI})$ in $48 \mathrm{~h}$ when the initial cell concentration was maintained at $10^{9}$ cells $/ \mathrm{mL}$; however, with 10 fold increase in cell density, $100 \mu \mathrm{M} \mathrm{Cr}(\mathrm{VI})$ was completely reduced in $30 \mathrm{~h}$. Increase in cell density stimulated $\mathrm{Cr}(\mathrm{VI})$ reduction process (Table 2 ) as has been reported with Bacillus sphaericus AND 303 [28], Pseudomonas CRB5 [29], Ochrobactrum intermedium SDCr-5 [30], Lysinibacillus fusiformis ZC1 [25], and Arthrobacter sp. SUK 1205 [27].

3.5. Effect of Different Electron Donors. The effect of different electron donors on $\mathrm{Cr}(\mathrm{VI})$ reduction by Arthrobacter sp. SUK 1201 cells was studied. The electron donors include glucose, glycine, glycerol, acetate, peptone, sucrose, propionate, yeast extract, benzoate, and tryptone, which were added at $0.1 \%$ concentration to the reaction mixture. Cells of SUK 1201 completely reduced $100 \mu \mathrm{M} \mathrm{Cr}(\mathrm{VI})$ in $12 \mathrm{~h}$ when glucose was used as the electron donor (Figure 3). Glycerol, acetate, and peptone as electron donors could have completely reduced the added $\mathrm{Cr}(\mathrm{VI})$ in $24 \mathrm{~h}$, while glycine and yeast extract appeared to be less efficient electron donors for reducing $\mathrm{Cr}(\mathrm{VI})$. Likewise, chromate reducing organisms are reported to utilize a variety of organic compounds as electron donors for $\mathrm{Cr}(\mathrm{VI})$ reduction [27, 31]. Whole cells of Arthrobacter sp. SUK 1205 [26], Ochrobactrum sp. strain CSCr-3 [24], and Bacillus cereus [32] were also found to utilize glucose as electron donor for efficient chromate reduction.

3.6. Effect of Temperature and $p H$. Environmental factors, such as temperature and $\mathrm{pH}$ were found to influence the chromate reducing potential of the viable cells of SUK 1201 (Figures 4(a) and 4(b)) as these two factors, in general, regulate the metabolic activities of the cells. The optimum temperature and $\mathrm{pH}$ for $\mathrm{Cr}(\mathrm{VI})$ reduction were $25^{\circ} \mathrm{C}$ (Figure $4(\mathrm{a})$ ) and 7.0 (Figure 4(b)), respectively. On either side of the $\mathrm{pH}$ and temperature scale, the reduction capability of the cells was impaired. Optimum temperature was found to range between $35^{\circ} \mathrm{C}-37^{\circ} \mathrm{C}$ with Ochrobactrum intermedium $\mathrm{Rb}-2$

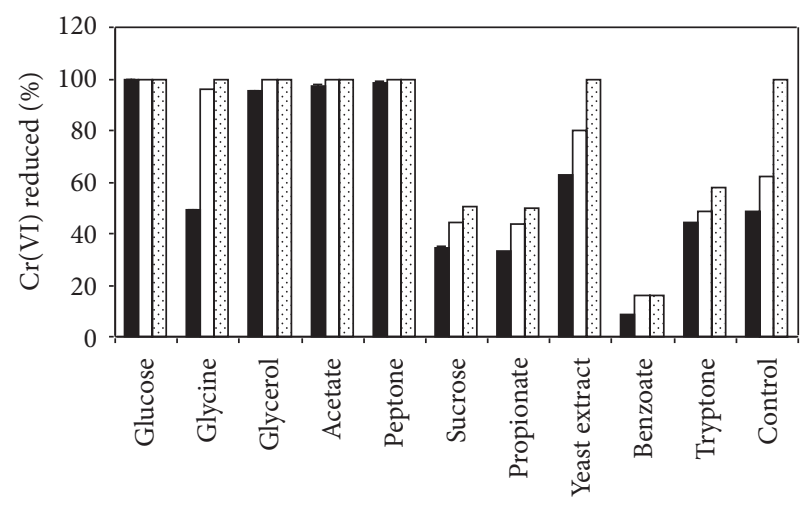

Electron donor

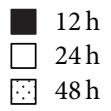

FIGURE 3: Effect of electron donor supplementation on Cr(VI) reduction by viable cells of Arthrobacter sp. SUK 1201. $[\mathrm{Cr}(\mathrm{VI})$ reduction was carried out in V. B. broth containing $100 \mu \mathrm{M}$ $\mathrm{Cr}(\mathrm{VI})$. The initial cell density was maintained at $10^{9}$ cells $/ \mathrm{mL}$. The electron donor was present at $0.1 \% \mathrm{w} / \mathrm{v}$ level, and $0.01 \% \mathrm{w} / \mathrm{v}$ glucose was present in control set. Incubation: $48 \mathrm{~h}$ at $25^{\circ} \mathrm{C}$ under continuous shaking $(120 \mathrm{rpm})$. Residual $\mathrm{Cr}(\mathrm{VI})$ was measured by diphenylcarbazide method. Results represent mean of triplicate experiments \pm standard error].

[33], Ochrobactrum sp. CSCr-3 [24], O. intermedium SDCr5 [30], and Nesterenkonia sp. MF2 [34]. It is presumed that deviation of these factors from their optima might alter the chromate reductase activity possibly due to change in the conformation and/or ionization of the enzyme [35].

3.7. Effect of Metal Ions. The process of chromate reduction is adversely affected by the presence of additional metal ions possibly due to metal toxicity and inhibition of the $\mathrm{Cr}(\mathrm{VI})$ reduction process [36]. Chromate reduction by viable cells of Arthrobacter sp. SUK 1201 was in general negatively affected when the reduction medium was supplemented with different heavy metals such as $\mathrm{Ni}(\mathrm{II}), \mathrm{Zn}(\mathrm{II}), \mathrm{Mn}(\mathrm{II})$, and $\mathrm{Co}(\mathrm{II})$ at equimolecular concentration. As compared to control, presence of $\mathrm{Ni}(\mathrm{II}), \mathrm{Zn}(\mathrm{II}), \mathrm{Mn}(\mathrm{II})$, and $\mathrm{Co}(\mathrm{II})$ showed nearly $66 \%$, $74 \%, 60 \%$, and $64 \%$ reduction, respectively (Table 3 ). However, $\mathrm{Cr}(\mathrm{VI})$ reducing capability of the isolate was enhanced when $\mathrm{Cu}(\mathrm{II})$ was present in the medium along with $\mathrm{Cr}(\mathrm{VI})$. 


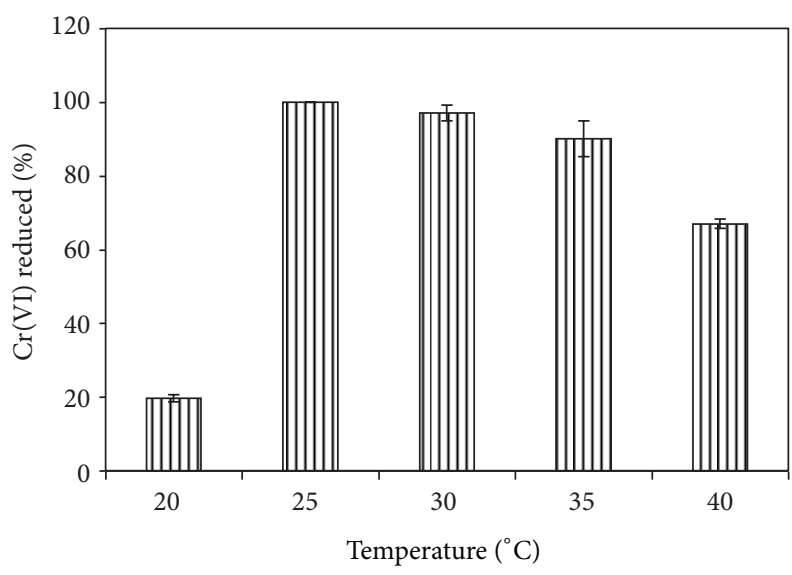

(a)

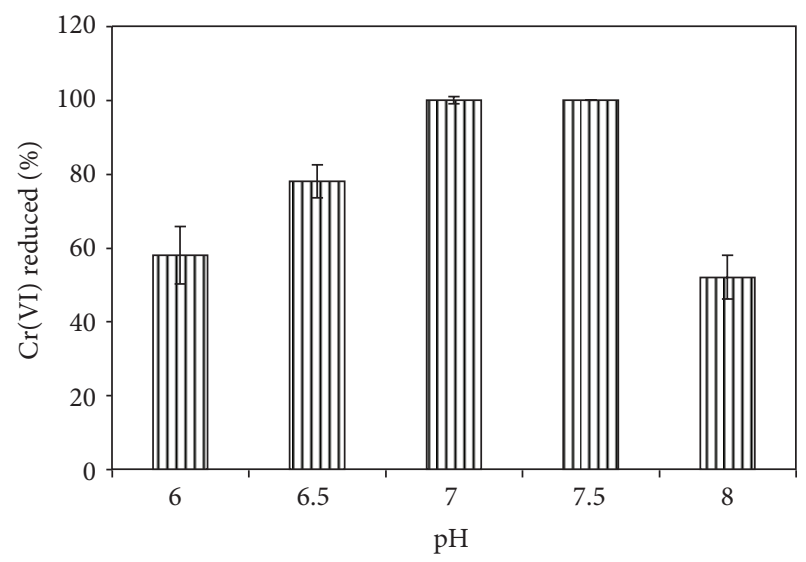

(b)

FIGURE 4: Effect of temperature (a) and $\mathrm{pH}$ (b) on chromate reduction by viable cells of Arthrobacter sp. SUK 1201. [Cr(VI)reduction was carried out in V. B. broth containing $100 \mu \mathrm{M} \mathrm{Cr}(\mathrm{VI})$. The initial cell density was maintained at $10^{9}$ cells $/ \mathrm{mL}$. The initial temperature was maintained from $20-40^{\circ} \mathrm{C}$ and $\mathrm{pH}$ of the reaction medium was maintained in the range of $\mathrm{pH} 6.0$ to 8.0 . Residual $\mathrm{Cr}(\mathrm{VI})$ was measured by diphenylcarbazide method. Results represent mean of triplicate experiments \pm standard error].

TABLE 3: Effect of metal ions on chromate reduction by viable cells of Arthrobacter sp. SUK 1201.

\begin{tabular}{|c|c|c|c|c|c|c|}
\hline \multirow[t]{2}{*}{ Incubation, hr } & \multicolumn{6}{|c|}{$\begin{array}{c}\% \mathrm{Cr}(\mathrm{VI}) \text { reduced } \\
\text { Metal ions, } 100 \mu \mathrm{M}\end{array}$} \\
\hline & Control (-Additional metal ions) & $\mathrm{Cu}(\mathrm{II})$ & $\mathrm{Ni}(\mathrm{II})$ & $\mathrm{Co}(\mathrm{II})$ & $\mathrm{Mn}(\mathrm{II})$ & $\mathrm{Zn}(\mathrm{II})$ \\
\hline 12 & $46.2 \pm 1.8$ & $81.4 \pm 3.2$ & $44.1 \pm 2.6$ & $53.0 \pm 2.0$ & $54.1 \pm 0.6$ & $48.0 \pm 0.4$ \\
\hline 24 & $60.2 \pm 2.6$ & $100 \pm 0.8$ & $53.0 \pm 1.6$ & $57.0 \pm 0.8$ & $60.0 \pm 1.6$ & $57.0 \pm 1.9$ \\
\hline 48 & $100 \pm 0.6$ & $100 \pm 0.2$ & $66.0 \pm 2.6$ & $74.0 \pm 1.0$ & $60.0 \pm 0.6$ & $63.4 \pm 2.4$ \\
\hline
\end{tabular}

$\left(\mathrm{Cr}(\mathrm{VI})\right.$ reduction was carried out in $\mathrm{V}$. B. broth containing $100 \mu \mathrm{M} \mathrm{Cr}(\mathrm{VI})$. The initial cell density was maintained at $10^{9}$ cells $/ \mathrm{mL}$. Separately sterilized metal solutions were added to V. B. broth at equimolar $(100 \mu \mathrm{M})$ level of $\mathrm{Cr}(\mathrm{VI})$.

Incubation: $48 \mathrm{~h}$ at $25^{\circ} \mathrm{C}$ under continuous shaking $(120 \mathrm{rpm})$. Residual $\mathrm{Cr}(\mathrm{VI})$ was estimated by usual diphenylcarbazide method. Results represent mean of triplicate experiments \pm standard error).

Such stimulatory effect of $\mathrm{Cu}(\mathrm{II})$ on $\mathrm{Cr}(\mathrm{VI})$ reduction activity has also been reported for $\mathrm{Cr}(\mathrm{VI})$-reduction by Bacillus sp. ES 29 [7], O. intermedium strain SDCr-5 [30], Ochrobactrum sp. strain CSCr-3 [24], Amphibacillus sp. KSUCr3, Bacillus sp. KSUCr9a [37, 38], and Arthrobacter sp. SUK 1205 [27]. The function of $\mathrm{Cu}(\mathrm{II})$ is either related to electron transport protection or to act as an electron redox centre, in some cases, as a shuttle for electrons between protein subunits $[7,24,39]$.

3.8. Effect of Inhibitors. Inhibitors of different type such as sodium azide $\left(\mathrm{NaN}_{3}\right)$, sodium fluoride $(\mathrm{NaF})$, 2,4dinitrophenol (DNP), carbonyl cyanide-m-chlorophenyl hydrazone (CCCP), and N,N,-Di cyclohexyl carbodiimide (DCC) (DCC) were used at equimolecular concentration to assess their influence on chromate reduction by viable cells of Arthrobacter SUK 1201. The influence of DNP was exceptionally different from the rest. In presence of DNP, cells of SUK 1201 could reduce nearly $80 \%$ of the $100 \mu \mathrm{M}$ $\mathrm{Cr}(\mathrm{VI})$ as compared to $50 \%$ reduction in the control in $24 \mathrm{~h}$ of incubation (Figure 5). On prolonged incubation $(48 \mathrm{~h})$, control and DNP treated cells completely reduced the $100 \mu \mathrm{M}$ of $\mathrm{Cr}(\mathrm{VI})$. Such promoting effect of DNP has also been reported in Burkholderia cepacia [40] and
Staphylococcus gallinarum [11] and Arthrobacter sp. SUK 1205 [27]. Further, it has been pointed out that DNP, being an uncoupler, might have accelerated the respiratory chain linked electron transport mechanism [40]. Amongst the rest, DCC was most inhibitory showing only 53\% $\mathrm{Cr}(\mathrm{VI})$ reduction and was followed by $\mathrm{NaN}_{3}$ and $\mathrm{NaF}$ ( $57 \%$ in both) and CCCP (71\%). These inhibitors are known to inhibit the activity of cytochrome oxidase and enolase [9], disrupt chemiosmotic gradient, and inhibit the ATPase activity.

3.9. Effect of Permeabilized Cells on Reduction. Freshly grown cells of Arthrobacter sp. SUK 1201 were permeabilized in presence of triton, toluene, and tween 80 and used for chromate reduction studies. Efficient reduction of hexavalent chromium was achieved with toluene treated cells in $24 \mathrm{~h}$ and was followed by cells treated with triton and tween 80 which took $42 \mathrm{~h}$ to reduce the total $\mathrm{Cr}(\mathrm{VI})$ in the media as against $48 \mathrm{~h}$ in the control (Figure 6). Permeabilized cells of Arthrobacter sp. SUK 1201 as induced by triton X-100, toluene, and tween 80 have enhanced the reduction of chromate (Figure 6), which might indicate that the $\mathrm{Cr}(\mathrm{VI})$ reduction is mediated by soluble protein of the cell [6]. Similar enhancement in $\mathrm{Cr}(\mathrm{VI})$ reduction rate was observed with Providencia sp. [41]. 


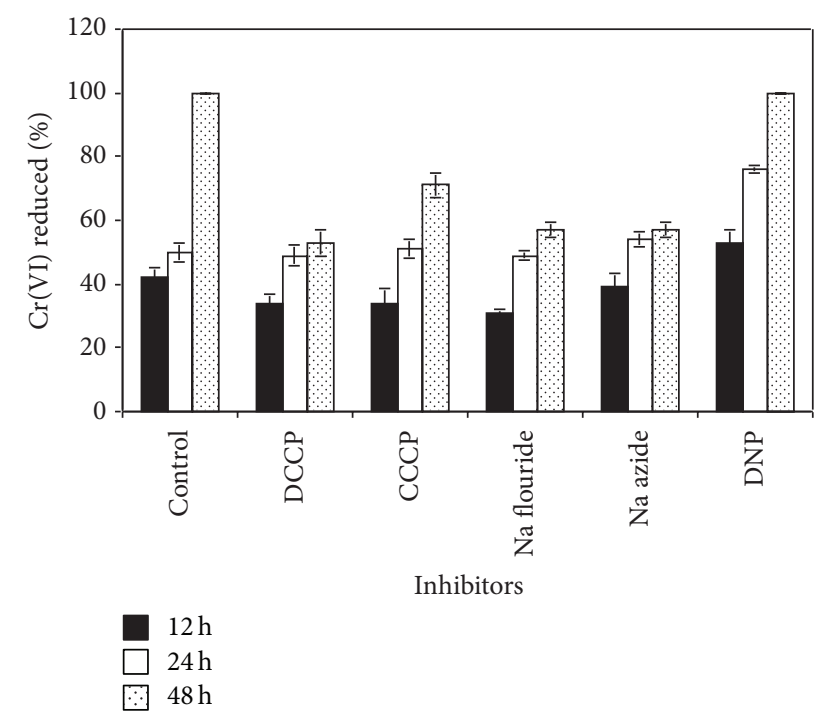

FIGURE 5: Effect of inhibitor on chromate reduction by viable cells of Arthrobacter sp. SUK 1201. [Cr(VI) reduction was carried out in V. B. broth containing $100 \mu \mathrm{M} \mathrm{Cr}(\mathrm{VI})$. The initial cell density was maintained at $10^{9}$ cells $/ \mathrm{mL}$. Incubation: $48 \mathrm{~h}$ at $25^{\circ} \mathrm{C}$ under continuous shaking $(120 \mathrm{rpm})$. All inhibitors were sterilized separately and added to V. B. broth at equimolar $(100 \mu \mathrm{M})$ level of $\mathrm{Cr}(\mathrm{VI})$. Residual $\mathrm{Cr}(\mathrm{VI})$ was estimated by usual diphenylcarbazide method. Results represent mean of triplicate experiments \pm standard error].

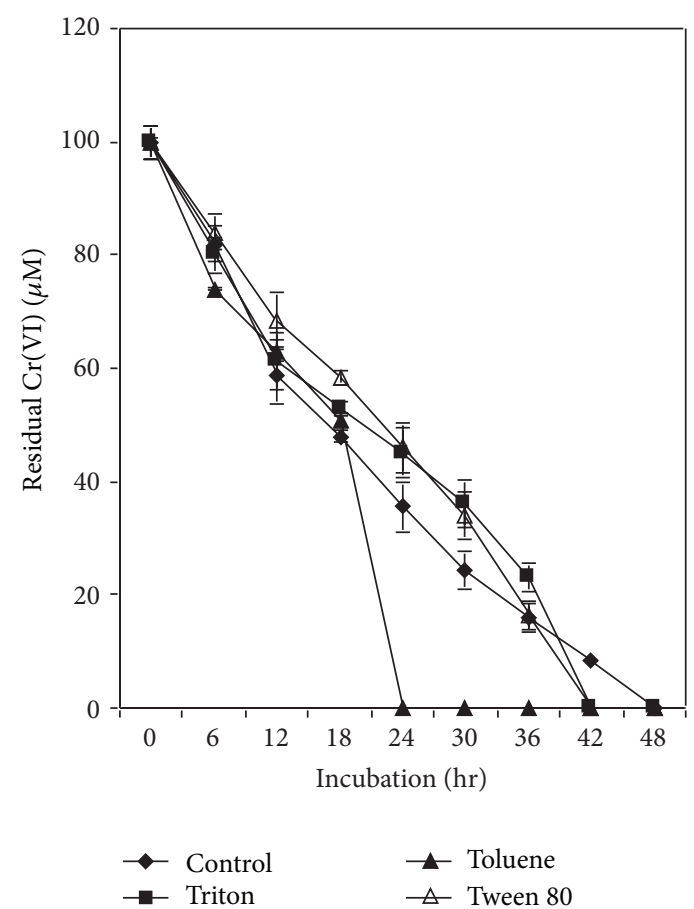

FIGURE 6: Hexavalent chromium reduction by permeabilized cells of Arthrobacter sp. SUK 1201. [Cr(VI) reduction was carried out in $\mathrm{V}$. B. broth containing $100 \mu \mathrm{M} \mathrm{Cr}(\mathrm{VI})$. The initial density of the permeabilized cells was maintained at $10^{9}$ cells $/ \mathrm{mL}$. Incubation: $48 \mathrm{~h}$ at $25^{\circ} \mathrm{C}$ under continuous shaking $(120 \mathrm{rpm})$. Residual $\mathrm{Cr}(\mathrm{VI})$ was estimated by usual diphenylcarbazide method. Results represent mean of triplicate experiments \pm standard error].

\section{Conclusion}

The optimization of different conditions of $\mathrm{Cr}(\mathrm{VI})$ reduction by viable cells of Arthrobacter SUK 1201 has categorically established the biotechnological potential of this bacterial strain for transformation of highly toxic and mutagenic $\mathrm{Cr}(\mathrm{VI})$ to less toxic $\mathrm{Cr}(\mathrm{III})$ and, thus, could be used in detoxification of chromium pollutants.

\section{Conflict of Interests}

The authors declare that there is no conflict of interests regarding the publication of this paper.

\section{Acknowledgment}

The authors acknowledge the financial support from the Department of Biotechnology, Ministry of Science and Technology, Government of India vide Sanction no. BT/PR/5766/ $\mathrm{NDB} / 51 / 061 / 2005$.

\section{References}

[1] R. K. Tiwary, R. Dhakate, V. Ananda Rao, and V. S. Singh, "Assessment and prediction of contaminant migration in ground water from chromite waste dump," Environmental Geology, vol. 48, no. 4-5, pp. 420-429, 2005.

[2] G. Godgul and K. C. Sahu, "Chromium contamination from chromite mine," Environmental Geology, vol. 25, no. 4, pp. 251257,1995

[3] H. J. Gibb, P. S. Lee, P. F. Pinsky, and B. C. Rooney, "Lung cancer among workers in chromium chemical production," American Journal of Industrial Medicine, vol. 38, pp. 115-126, 2000.

[4] H. J. Gibb, P. S. Lee, P. F. Pinsky, and B. C. Rooney, "Clinical findings of irritation among chromium chemical production workers," American Journal of Industrial Medicine, vol. 38, no. 2, pp. 127-131, 2000.

[5] M. R. Bruins, S. Kapil, and F. W. Oechme, "Microbial resistance to metallothionein in the environment," Journal of Environmental Microbiology, vol. 45, no. 1, pp. 351-364, 2000.

[6] U. Thacker and D. Madamwar, "Reduction of toxic chromium and partial localization of chromium reductase activity in bacterial isolate DM1," World Journal of Microbiology and Biotechnology, vol. 21, no. 6-7, pp. 891-899, 2005.

[7] F. A. O. Camargo, B. C. Okeke, F. M. Bento, and W. T. Frankenberger, "In vitro reduction of hexavalent chromium by a cell-free extract of Bacillus sp. ES 29 stimulated by $\mathrm{Cu}^{2+}$," Applied Microbiology and Biotechnology, vol. 62, no. 5-6, pp. 569-573, 2003.

[8] K. H. Cheung and J. D. Gu, "Reduction of chromate $\left(\mathrm{CrO}_{4}^{2-}\right)$ by an enrichment consortium and an isolate of marine sulfatereducing bacteria," Chemosphere, vol. 52, no. 9, pp. 1523-1529, 2003.

[9] D. J. Opperman and E. van Heerden, "Aerobic $\mathrm{Cr}(\mathrm{VI})$ reduction by Thermus scotoductus strain SA-01," Journal of Applied Microbiology, vol. 103, no. 5, pp. 1907-1913, 2007.

[10] S. Farag and S. Zaki, "Identification of bacterial strains from tannery effluent and reduction of hexavalent chromium," Journal of Environmental Biology, vol. 31, no. 5, pp. 877-882, 2010. 
[11] M. Z. Alam and S. Ahmad, "Toxic chromate reduction by resistant and sensitive bacteria isolated from tannery effluent contaminated soil," Annals of Microbiology, vol. 62, no. 1, pp. 113-121, 2012.

[12] S. Dey and A. K. Paul, "Occurrence and evaluation of chromium reducing bacteria in seepage water from chromite mine quarries of Orissa, India," Journal Water Research Protection, vol. 2, pp. 380-388, 2010.

[13] S. Dey and A. K. Paul, "Optimization of cultural conditions for growth associated chromate reduction by Arthrobacter sp. SUK 1201 isolated from chromite mine overburden," Journal of Hazardous Materials, vol. 213-214, pp. 200-206, 2012.

[14] S. Dey and A. K. Paul, "Hexavalent chromium reduction by aerobic heterotrophic bacteria indigenous to chromite mine overburden," Brazilian Journal of Microbiology, vol. 44, no. 1, pp. 307-315, 2013.

[15] Y. Wang and C. Xiao, "Factors affecting hexavalent chromium reduction in pure cultures of bacteria," Water Research, vol. 29, no. 11, pp. 2467-2474, 1995.

[16] J. J. Calomiris, J. L. Armstrong, and R. J. Seidler, "Association of metal tolerance with multiple antibiotic resistance of bacteria isolated from drinking water," Applied and Environmental Microbiology, vol. 47, no. 6, pp. 1238-1242, 1984.

[17] C. H. Park, M. Keyhan, B. Wielinga, S. Fendorf, and A. Matin, "Purification to homogeneity and characterization of a novel Pseudomonas putida chromate reductase," Applied and Environmental Microbiology, vol. 66, no. 5, pp. 1788-1795, 2000.

[18] D. Bagchi, S. J. Stohs, B. W. Downs, M. Bagchi, and H. G. Preuss, "Cytotoxicity and oxidative mechanisms of different forms of chromium," Toxicology, vol. 180, no. 1, pp. 5-22, 2002.

[19] E. Ezaka and C. U. Anyanwu, "Chromium (VI) tolerance of bacterial strains isolated from sewage oxidation ditch," International Journal of Environmental Science, vol. 1, pp. 1725-1734, 2011.

[20] W. C. Bae, H. K. Lee, Y. C. Choe et al., "Purification and characterization of NADPH-dependent $\mathrm{Cr}(\mathrm{VI})$ reductase from Escherichia coli ATCC 33456," Journal of Microbiology, vol. 43, no. 1, pp. 21-27, 2005.

[21] R. Elangovan, S. Abhipsa, B. Rohit, P. Ligy, and K. Chandraraj, "Reduction of $\mathrm{Cr}(\mathrm{VI})$ by a Bacillus sp.," Biotechnology Letters, vol. 28, no. 4, pp. 247-252, 2006.

[22] P.-. Wang, T. Mori, K. Komori, M. Sasatsu, K. Toda, and H. Ohtake, "Isolation and characterization of an Enterobacter cloacae strain that reduces hexavalent chromium under anaerobic conditions," Applied and Environmental Microbiology, vol. 55, no. 7, pp. 1665-1669, 1989.

[23] P.-. Wang, K. Toda, H. Ohtake, I. Kusaka, and I. Yabe, "Membrane-bound respiratory system of Enterobacter cloacae strain HO1 grown anaerobically with chromate," FEMS Microbiology Letters, vol. 78, no. 1, pp. 11-15, 1991.

[24] Z. He, F. Gao, T. Sha, Y. Hu, and C. He, "Isolation and characterization of a Cr(VI)-reduction Ochrobactrum sp. strain CSCr-3 from chromium landfill," Journal of Hazardous Materials, vol. 163, no. 2-3, pp. 869-873, 2009.

[25] M. He, X. Li, H. Liu, S. J. Miller, G. Wang, and C. Rensing, "Characterization and genomic analysis of a highly chromate resistant and reducing bacterial strain Lysinibacillus fusiformis ZC1," Journal of Hazardous Materials, vol. 185, no. 2-3, pp. 682688, 2011.

[26] M. Megharaj, S. Avudainayagam, and R. Naidu, "Toxicity of hexavalent chromium and its reduction by bacteria isolated from soil contaminated with tannery waste," Current Microbiology, vol. 47, no. 1, pp. 51-54, 2003.

[27] S. Dey and A. K. Paul, "Optimization of chromate reduction by whole cells of Arthrobacter sp. SUK 1205 isolated from metalliferous chromite mine environment," Geomaterials, vol. 2, no. 4, pp. 73-81, 2012.

[28] A. Pal and A. K. Paul, "Aerobic chromate reduction by chromium-resistant bacteria isolated from serpentine soil," Microbiological Research, vol. 159, no. 4, pp. 347-354, 2004.

[29] J. S. McLean, T. J. Beveridge, and D. Phipps, "Isolation and characterization of a chromium-reducing bacterium from a chromated copper arsenate-contaminated site," Environmental Microbiology, vol. 2, no. 6, pp. 611-619, 2000.

[30] S. Sultan and S. Hasnain, "Reduction of toxic hexavalent chromium by Ochrobactrum intermedium strain SDCr-5 stimulated by heavy metals," Bioresource Technology, vol. 98, no. 2, pp. 340-344, 2007.

[31] Y. G. Liu, W. H. Xu, and G. M. Zeng, "Experimental study on reduction by Pseudomonas aeruginosa," Journal of Environmental Sciences, vol. 16, no. 5, pp. 797-801, 2004.

[32] Y.-T. Wang and H. Shen, "Bacterial reduction of hexavalent chromium," Journal of Industrial Microbiology, vol. 14, no. 2, pp. 159-163, 1995.

[33] R. Batool, K. Yrjälä, and S. Hasnain, "Hexavalent chromium reduction by bacteria from tannery effluent," Journal of Microbiology and Biotechnology, vol. 22, no. 4, pp. 547-554, 2012.

[34] M. A. Amoozegar, A. Ghasemi, M. R. Razavi, and S. Naddaf, "Evaluation of hexavalent chromium reduction by chromateresistant moderately halophile, Nesterenkonia sp. strain MF2," Process Biochemistry, vol. 42, no. 10, pp. 1475-1479, 2007.

[35] S. O. Farrell and R. T. Ranallo, Experiments in Biochemistry. A Hands-On Approach, Saunders College Publications, Orlando, Fla, USA, 2000.

[36] J. Mclean and T. J. Beveridge, "Chromate reduction by a Pseudomonad isolated from a site contaminated with chromated copper arsenate," Applied and Environmental Microbiology, vol. 67, no. 3, pp. 1076-1084, 2001.

[37] A. S. S. Ibrahim, M. A. El-Tayeb, Y. B. Elbadawi, and A. A. Al-Salamah, "Isolation and characterization of novel potent $\mathrm{Cr}(\mathrm{VI})$ reducing alkaliphilic Amphibacillus sp. KSUCR3 from hypersaline soda lakes," Electronic Journal of Biotechnology, vol. 14, no. 4, p. 4, 2011.

[38] A. S. S. Ibrahim, M. A. El-Tayeb, Y. B. Elbadawi, and A. A. AlSalamah, "Bioreduction of cr (VI) by potent novel chromate resistant alkaliphilic Bacillus sp. strain ksucr5 isolated from hypersaline soda lakes," African Journal of Biotechnology, vol. 10, no. 37, pp. 7207-7218, 2011.

[39] F. Abe, T. Miura, T. Nagahama, A. Inoue, R. Usami, and K. Horikoshi, "Isolation of a highly copper-tolerant yeast, Cryptococcus sp., from the Japan Trench and the induction of superoxide dismutase activity by $\mathrm{Cu}^{2+}$, Biotechnology Letters, vol. 23, no. 24, pp. 2027-2034, 2001.

[40] R. Wani, K. M. Kodam, K. R. Gawai, and P. K. Dhakephalkar, "Chromate reduction by Burkholderia cepacia MCMB-821, isolated from the pristine habitat of alkaline crater lake," Applied Microbiology and Biotechnology, vol. 75, no. 3, pp. 627-632, 2007.

[41] U. Thacker, R. Parikh, Y. Shouche, and D. Madamwar, "Hexavalent chromium reduction by Providencia sp.", Process Biochemistry, vol. 41, no. 6, pp. 1332-1337, 2006. 

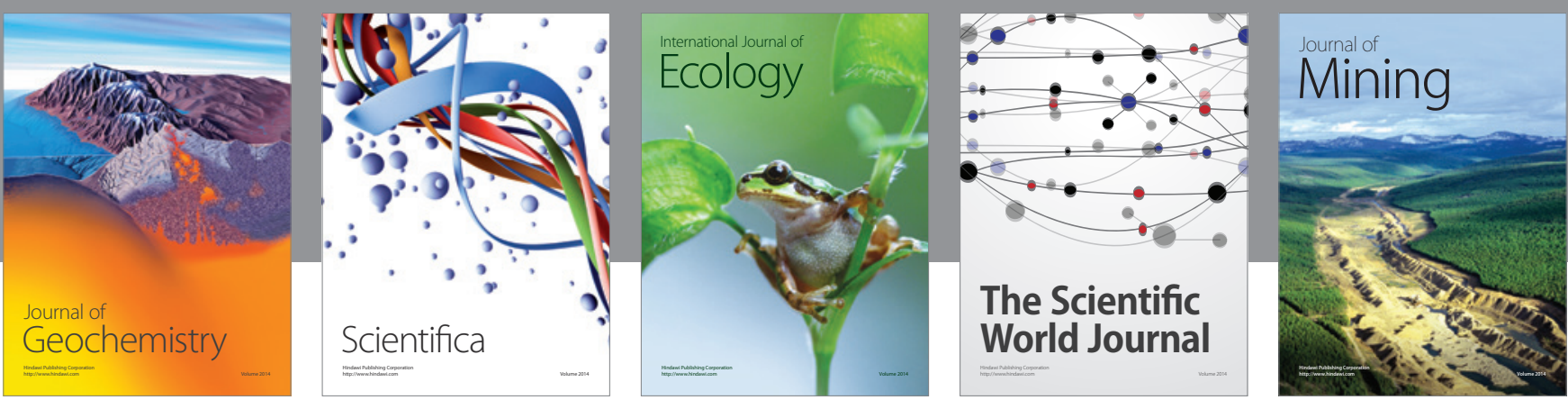

The Scientific World Journal
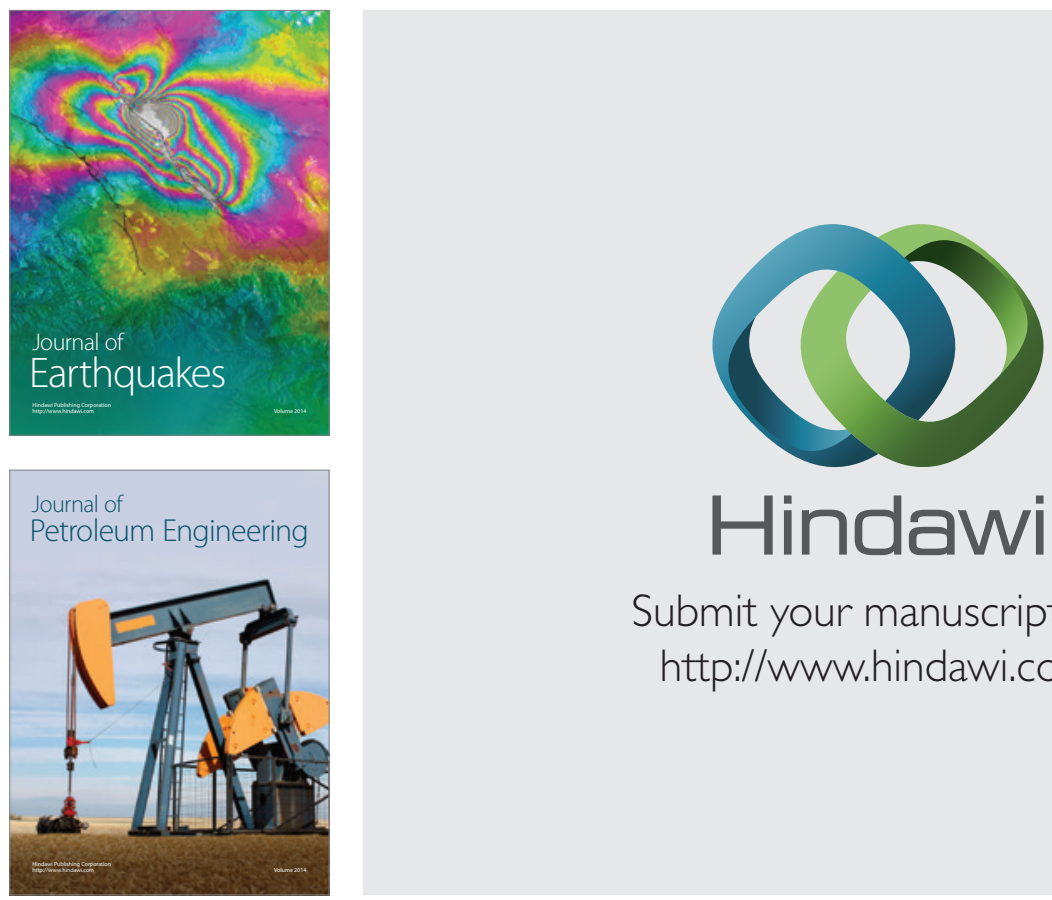

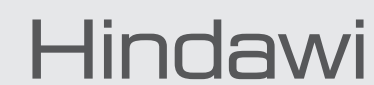

Submit your manuscripts at

http://www.hindawi.com
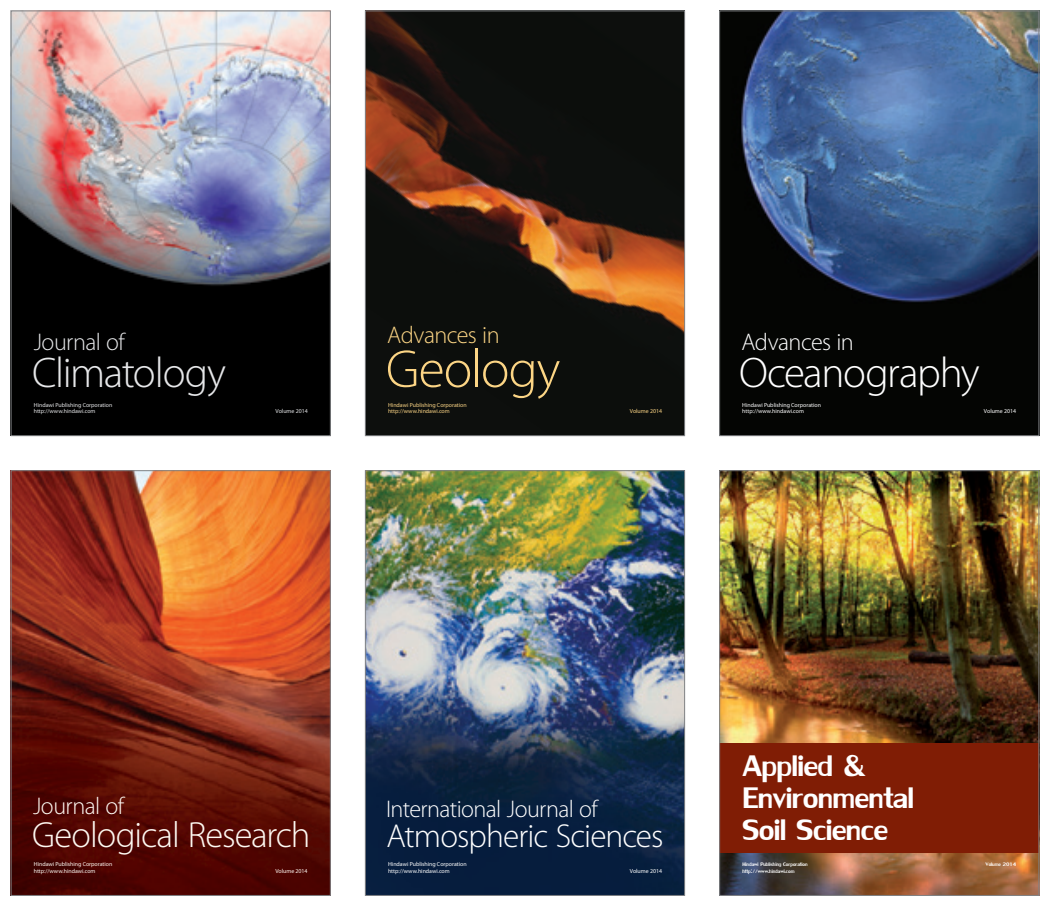
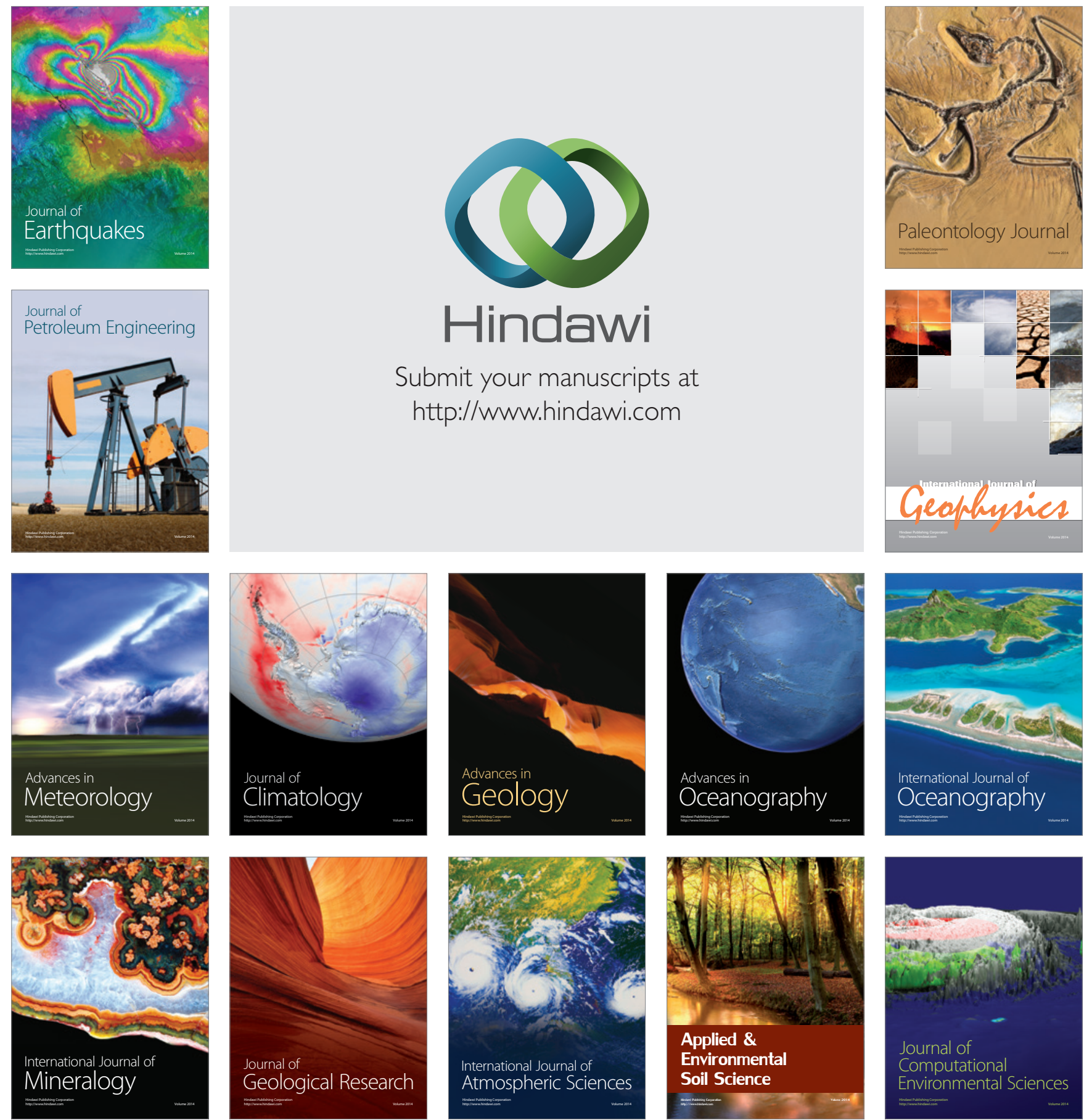